\title{
Promotion of Individual and Group Creativity during Process of Management Decision Making at Kosovo Businesses
}

Zymer Tafaj

Security Force of Kosovo, Isniq-Deçan

Fatos Turkaj

University "Haxhi Zeka" - Pejë, Dubravë-Deçan

Safete Hadergjonaj

College of Business- Prishtinë, Deçan

\section{Doi:10.5901/ajis.2015.v4n2p491}

\section{Abstract}

This paper elaborates topic about promotion of individual and group creativity during process of decision-making, managers during their work often have to take decisions from which depends success and failure of business. Time to time they have to generate new ideas, so they are those who should give opportunity for individual and group creativity at their business. One of the ways to promote individual creativity is employees' involvement in the process of placement this enables manager to generate new ideas, on the other side employees become more responsible and motivated. While group creativity is important for solving complex problems of business. The main purpose of paper is reflection of promoting individual and group creativity during process of decision making by managers of Kosovo businesses, this promotion helps them with generating the ideas and making right decisions that affect in achieving the purpose of business on the other side employees feel more responsible and motivated to work. Paper consist of two parts, theoretical part that explains theatrical aspect about importance of promoting individual and group creativity during decision making and it is based on secondary and tertiary data, by using deductive method, while at second part it is used inductive method and it is based on data collected in the field through survey. During research work quantitative method applies, and two surveys are drafted and surveyed 1,900 business managers that in average are 50 managers in 38 Municipalities of Kosovo and 100 employees for each Municipality, respectively 3800 employees. Surveys are designed in that way, where answers on questions help to elaborate base ideas or hypotheses of this work and through their results we reach to the confirmation or denial of hypotheses. The derived data are presented in graphical and tabular form. Among the main findings of the paper are that majority of managers at Kosovo businesses declare that they promote individual and group creativity during decision making but they don't realize it in practice because majority of employees declare that their ideas are not taken in consider during decision making so they are not included in this process. While as recommendation they should start promoting individual and group creativity during process of decision making at Kosovo businesses because it helps in right decision-making of business.

Keywords: decision making, manager, creativity, business, individual, group

\section{Introduction}

Decision making is the most important activity of management, mangers occasionally face problems that require quickly solutions and decision making and their choices are to make decision by their own or to generate idea and solution from their staff in a way to make this process easier. So managers during their work often should make decisions and from those success or failure of business depends. They occasionally have to generate new ideas, so they are those who should give opportunity to individual and group creativity at their businesses. One of the ways to promote individual creativity is involvement of employees in process of decision making, this helps manager to generate new ideas while on the other side it makes employees more responsible and motivated. Where as group creativity is important for solving complex problems of business.

The main purpose of this paper is reflection of promoting individual and group creativity during process of decision making by managers of Kosovo businesses, because this promotion helps them to generate new ideas and make right decisions that affect on achieving the business purposes, on the other side employees feel more responsible and 
motivated to work. So let's compare the positions of managers and employees. The research question of the paper is: Is it promoted the individual and group creativity at Kosovo businesses?

The paper consists of two parts, theoretical part that explains theoretical aspect of importance of promoting individual and group creativity during process of decision making and relies on secondary and tertiary data by using deductive method, whereas at second part is used inductive method and relies on primary data collected in the field through survey.

During research work, applies quantitative method and are designed two surveys and surveyed 1900 managers of businesses that in average are 50 managers in 38 Municipalities of Kosovo and 100 employees for each Municipality, respectively 3800 employees. Surveys are drafted in that way that answers of questions help to elaborate base ideas or hypotheses of this paper and through their results we reach to the confirmation or denial of hypotheses. Derived data are presented in graphical and tabular. Also descriptive, analytical and comparative methods are applied in our research work. Samples from where data are taken are managers and employees of Kosovo businesses that were selected in random.

As main finding of work is that majority of managers at Kosovo businesses declare that they promote individual and group creativity during process of decision making they say that they have such a working environment that employees express freely their ideas and they are recognized and rewarded in that way to be motivated, they also say that they use techniques of brainstorming, nominated group and Delphi to promote group creativity but they don't realize this in practice because majority of employees declare that their ideas are not taken in consider during the decision making, so they are not involved in this process.

So at businesses where they work do not promote individual and group creativity, because they don't use techniques that encourage group creativity during process of decision making. Whereas as recommendation is to start promotion of individual and group creativity at Kosovo businesses during decision making because this helps them in making right business decisions and employees will be more motivated and feel more responsible for their activities counting themselves as part of decision making and their efforts for results will increase and this will result with their best performance, managers also will have many ideas available to solve problems and make right decisions.

\section{The Hypotheses of the Paper}

H1: Majority of managers at Kosovo businesses declare that in their working environment,promote individual and group creativity to generate new ideas during the meeting with problems and process of decision making.

$\mathrm{H} 2$ : Majority of managers at Kosovo businesses declare that they have created such a working environment where their employees freely can take and express initiatives and ideas that help in process of decision making.

H3: Majority of managers at Kosovo businesses declare that they recognize and reward ideas of talented employees, because this encourages them to be more active and to give new useful ideas.

H4: Majority of managers at Kosovo businesses declare that they promote group creativity by using "Brainstorming" where they meet face to face with employees to generate ideas that help in making decisions.

H5: Majority of managers at Kosovo businesses declare that they promote group creativity by using technique of nominal group where they describe problem and employees in independent way write solutions than discuss and choose the best idea.

H6: Majority of managers at Kosovo businesses declare that they promote group creativity by using Delphi technique that presents a written approach to the creative solution of the problem.

$\mathrm{H7}$ : Majority of employees at Kosovo businesses declare that at the environment where they work cannot be taken free initiatives to give ideas for solving a problem and decision making.

H8: Majority of employees at Kosovo businesses declare that at the environment where they work does not happen to recognize and reward talented employees that give good ideas that help in process of decision making.

H9: Majority of employees at Kosovo businesses declare that at their working environment is not promoted individual creativity to generate new ideas that help in process of decision making.

H10: Majority of employees at Kosovo businesses declare that at their working environment is not promoted group creativity and does not happen to be used technique of "Brainstorming", where they meet face to face with managers to give ideas that help them in decision making.

H11:Majority of employees at Kosovo businesses declare that at their working environment is not promoted group creativity and does not happen to be used technique of nominal group where managers describe the problem, 
and they in independent way write the solutions than discuss and resolve the best idea.

H12: Majority of employees at Kosovo businesses declare that at their working environment is not promoted group creativity and does not happen to be used technique of Delphi that presents a written approach to the creative solution of the problem.

\section{Management and Decision Making}

Management presents process of aware orientation of human activities towards the realization of specific purpose/purposes, respectively the cross-linked entirety of five functions: planning, organizing, staff (personnel, leadership and control: Ramosaj, 1991, 24). It is the process of forming and maintaining the environment in which individuals by working together achieve goals previously set(Ëeihrich \& Koontz, 1993, 4). So management has to do with those people or individual who deal with managerial work oriented towards goals realization at organizations, which we call management work (Ramosaj, 2007, 20). Management is a universal process of formulation and realization of goals of the organization even through other people, by using managerial functions of planning, organizing, leadership and control, also coordination of resources in efficient and effective way (Zeqiri, 2006, 6).It presents the process through which, the chosen group of people lead and orientate all the employees at the company according to joint task for joint purpose (Massic \& Douglas, 1973, 24).

Management is the process through which the members and the organization's efforts are coordinated and oriented towards achieving the goals of organization (Kuka et al, 2006, 385). Management refers to the process of carrying out activities in efficient way even through other persons. Four key processes of management are: planning (setting goals),organizing (how to achieve these goals),leadership (motivation of employees) and also control that has to do with monitoring the activities (Robbins \&DeCenzo, 2011, 53). So management or economic direction represents the complex process of organization and direction of a company, institution or organization, to provide investment and efficient use of material resources, financial and human recourses through planning, coordinating and activity control, selection of employees and optimizing the decision making process for achieving certain objectives(Skenderi, 2010, 147) Management is a process of aware orientation through which personnel management organizes and orients employees of company according to joint task for joint purpose, by coordinating different resources at process of planning, organizing and control (Konini \& Peçi, 1997, fq.184).

Management is realized through managers that in work process unite and coordinate rare resources to achieve organizational objectives, they accept the risk, make decisions, interconnect a wide range of economic factors, social and technical (Koleci et al, 2008, 20). Each of the organizations to achieve a purpose, involves a range of human, material and financial resources, and manager is the one who through management in work process unite and coordinate these recourses to achieve objectives of organization (Kuka et al, 2006, 21).Management process is realized through managers, and they are persons who take tasks and governance functions of any level or any organizational form (Ramosaj, 2007, 308). Manager is called the person who is in charge of: control, organizing and partial or full running of the business of a society or organization (Konini \& Peçi, 1997, 184).

Managers work is not easy it is complicated and too dimensional, so one manager to be effective should have four general skills: conceptual, communicative, technical and political skills (Robbins \&DeCenzo, 2011, 45). Managers task is to accept the risk and to make decisions at dynamic environment where a wide range of economic, social and technical factors are intertwined and influenced that act as innovators in the presentation and introduction of new products and services of modern technology (Kuka et al, 2006, 21). At work process managers should play a wide range of roles and possess a range of skills to accomplish their task. Among the key roles of manager are: a) interpersonal role: central figure, leader, liaison, b) informatory: watcher, distributors, spokesperson, negotiator and c) decision maker: entrepreneur, conflict handler, resource allocator (Koleci et al, 2008, 45).

Process of decision making is too important for managers during their engagement in planning, organizing, coordinating, motivating and controlling, since they permanently decide to make decisions (Zeqiri, 2006, 149). Decision making is an attempt of a manger to achieve the purpose of the organization by choosing alternatives between two or more of them, with which ones the action is directed to solve the problem (Koleci et al, 2008, 113). Decision-making is one of the most important stages of the process of governance, during which decide what,how and for whom to produce (Sell). This process is usually accomplished by carefully analyzing different alternatives (Skenderi, 2010, 262 ). Making decisions is one of the most important activities of special individuals of groups or organizations, that is the choice by which a person or a group of people draw a conclusion about a certain situation, it is the process of choosing an alternative among a set of possible alternatives (Llaci, 2002, 111). Decision making is a process of defining the problem, 
formulation of alternatives for problem solving, choosing the best alternative, implementation of choice and its control (Zeqiri, 2006,143). There are four decision making models: physical, schematic, mathematical and probabilistic (Ramosaj, 2007, 58).

Separation and simple classification of the types of decisions would be in: routine decisions and not routine, whereas the most sophisticated separation of decision types it is done in routine decisions, adaptive and innovative, but there are also programmed and un-programmed decisions, proactive and reactive decisions and intuitive and systematic decisions (Koleci et al, 2008, 108-110). In general types of decisions can be grouped in: strategic, tactical and administrative decisions (Ramosaj, 2007, 57). Decision making is a whole of several steps that include the identifying of problem, selection of a solution for this problem and assessing the effectiveness of this solution (Robbins \&DeCenzo, 2011, 45).

\section{Promotion of Individual and Group Creativity during Process of Decision Making}

Managers should provide opportunities for creativity in organizations to generate new ideas, to do this it should be created an environment of a free initiative, experimentation, verification and failure, as an opportunity to learn from mistakes (Zeqiri, 2006, 161). Successful realization of the creative process requires from manager to rely on two basic elements: convergent thinking as an attempt to solve problems starting from him and walking in a logical manner towards solving the problem and divergent thinking as an attempt for solving the problem by suggesting different ways and searching new alternatives (Llaci, 2002, 137). The quality of decision making by managers depends heavily on their creativity and innovative responsibility to respond to the challenges that face the organizations (Zeqiri, 2006, 160). Formulating a creative idea is not processing of any known idea, but a totally new process and consists of the following sub stages: familiarity with the problem, collection of data from many sources, incubation (for data should think deeply, elimination (new thinking about the problem) and verification (if the choice will work) (Ramosaj, 2007, 55).

Promotion of individual creativity is involving of employees at process of decision making, knowing that they work on vital issues for organization, to be more responsible and motivated besides this also recognition of ideas of talented employees and their reward is an encouragement of individual creativity (Zeqiri, 2006, 161). In practice a considerable part of the decisions are taken by a group of people so managing boards make decisions for the future of the company, project teams get involved in solving the problem, So the nature of the problems and the size of their impact,in the organization affect in that way if decisions should be taken by groups or individuals (Llaci, 2002, 137). Promotion of group creativity is important for solving complex problems under conditions of uncertainty and innovative decision making, because decision making in group enables the combination of more experiences, generating more ideas and processing of more information (Zeqiri, 2006, 159).

A number of promotion techniques of creativity and decision making in groups are: Brainstorming, Nominal Group technique and Delphi technique (Kuka et al, 2006, 148).

$\Rightarrow$ Technique of Brainstorming: is decision making technique where managers meet face to face with employees and throw many ideas which than will be modified and improved (Llaci, 2002, 141).

$\Rightarrow$ Technique of nominal groups: is technique of decision making in which group members are physically present but operate independently (Robbins \&DeCenzo, 2011, 45).

$\Rightarrow$ Technique of Delphi: presents a written approach towards creative solution of problem (Zeqiri, 2006, 162).

Individual decisions and also those in groups have their own power and none of them is ideal for all situations but in different situations have their advantages and disadvantages (Robbins \& DeCenzo, 2011, 45).

\section{Results of the Research - Analysis of Data}

To reach appropriate conclusions, and to express in the most comprehensive attitudes about promoting individual and group creativity during process of decision making by managers of Kosovo businesses, was drafted a survey which one is focused at managers and employees of businesses and presents their attitudes about this phenomenon.

During research work applies quantitative method where are drafted two surveys and survey 1900 managers of businesses that in average are 50 managers in 38 Municipalities of Kosovo and 100 employees for each Municipality, respectively 3800 employees. Surveys are drafted in that way, where answers of questions help to elaborate the base ideas or hypothesis of this paper and through their results we reach to the confirmation or denial of hypotheses. The derived data are presented in graphical and tabular form. Also descriptive, analytical and comparative methods are applied in our research work. Samples from where data are taken are managers and employees of Kosovo businesses, 
who were selected in random.

Now let's see the achieved results.

1. Do you give opportunity for individual creativity to generate new ideas?

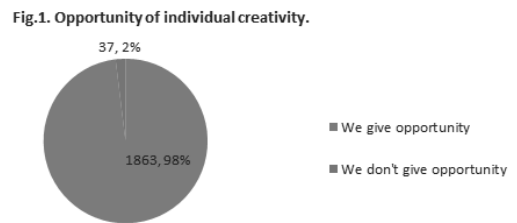

At the above figure 1. it can be seen that majority or $98 \%$ (1863) of managers at Kosovo businesses declare that during their work they give opportunity for individual creativity to generate new ideas whereas $2 \%$ (37) of them declare that they don't do this. Results of this figure certify our first hypothesis.

2. Have you created environment of free initiative?

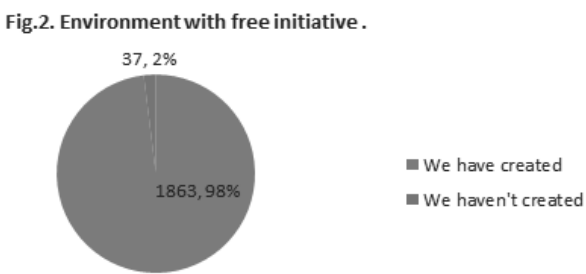

At the above figure 2. it can be seen that majority or $98 \%$ (1863) of managers at Kosovo businesses declare that during their work they have created environment of free initiative to generate new ideas whereas $2 \%$ (37) of them declare that they don't do this. Results of this figure certify our second hypothesis.

3. Do you identify and reward ideas of talented employees?

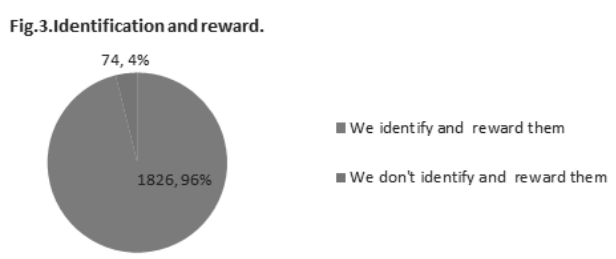

At the above figure 3. it can be seen that majority or $96 \%$ (1826) of managers at Kosovo businesses declare that they identify and reward talented employees who give new ideas to help on decision making whereas $4 \%(74)$ of them declare that they don't do this. Results of this figure certify our third hypothesis.

4. Do you use the Brainstorming technique to promote group creativity?

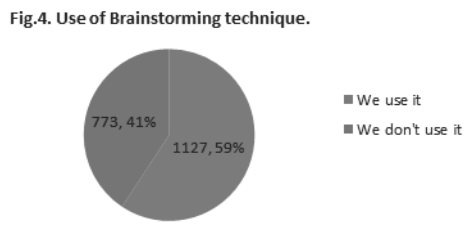

At the above figure 4. it can be seen that majority or 59\% (1127) of managers at Kosovo businesses declare that they use technique of Brainstorming to promote group creativity and generate new ideas that help on decision making process whereas $41 \%$ (773) of them declare that they don't do this. Results of this figure certify our fourth hypothesis. 
5. Do you use the nominal group technique to promote group creativity?

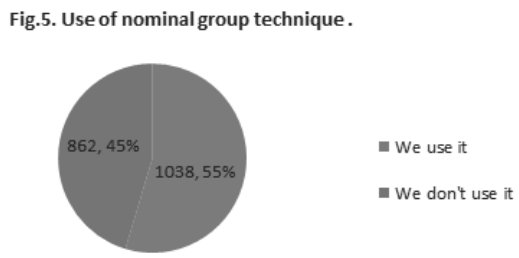

At the above figure 5. it can be seen that majority or 55\% (1038) of managers at Kosovo businesses declare that they use technique of nominal group to promote group creativity and generate new ideas that help on decision making process whereas $45 \%$ (862) of them declare that they don't do this. Results of this figure certify our fifth hypothesis.

6. Do you use the Delphi technique to promote group creativity?

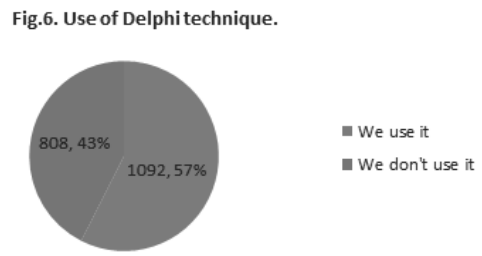

At the above figure 6. it can be seen that majority or $57 \%$ (1092) of managers at Kosovo businesses declare that they use the Delphi technique to promote group creativity and generate new ideas that help on decision making process whereas $43 \%$ (808) of them declare that they don't do this. Results of this figure certify our sixth hypothesis.

At the following figures will be presented attitudes of employees about individual and group creativity promotion in practice at Kosovo businesses.

7. Can you have a free initiative in your work environment, to give creative ideas about problem solutions?



At the above figure 7. it can be seen that majority or 52\% (1982) of employees at Kosovo businesses declare that during their work they don't have opportunity of having free initiative to generate new ideas whereas $48 \%$ (1818) of them declare that they can do it. Results of this figure certify our seventh hypothesis.

8. Does may happen to identify and reward the good ideas?

Fig.8. Practice of recognition and reward of employees.



It happen

It doesn't happen

At the above figure 8. it can be seen that majority or 63\% (2411) of employees at Kosovo businesses declare that during their work does not happen to be recognized and rewarded the talented employees that give ideas whereas 37\% (1389) of them declare that this happen during their work. Results of this figure certify our eighth hypothesis. 
9. Is it promoted individual creativity at your work environment?

Fig.9. Practice of promoting individual creativity.

At the above figure 9. it can be seen that majority or $52 \%$ (1982) of employees at Kosovo businesses declare that during their work is not promoted individual creativity whereas $48 \%$ (1818) of them declare that it is promoted. Results of this figure certify our ninth hypothesis.

10. Do you meet in group in front of managers to give ideas face to face for solution of any problem?

Fig.10. Practice use of Brainstorming technique.

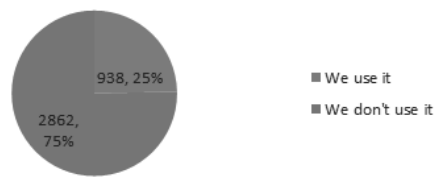

At the above figure 10. it can be seen that majority or $75 \%$ (2862) of employees at Kosovo businesses declare that during their work is not used Brainstorming technique, whereas $25 \%$ (938) of them declare that they use this technique. Results of this figure do not match with attitudes of managers and these results certify our tenth hypothesis.

11. Does may happen that you write your ideas about solution of different problems and present them and then to be chosen as the best idea?

Fig.11. Practice of the nominal group technique.

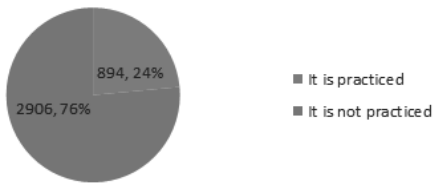

At the above figure 11. it can be seen that majority or $76 \%$ (2906) of employees at Kosovo businesses declare that during their work is not used the nominal group technique for promotion of group creativity, whereas $24 \%$ (894) of them declare that they use this technique. Results of this figure do not match with attitudes of managers and these results certify our eleventh hypothesis.

12. Does may happen you to give creative ideas by writing for any problem solution?

Fig.11. Practice of Delphitecnique.



It happens

It doesn't happen

At the above figure 12 it can be seen that majority or $76 \%$ (2889) of employees at Kosovo businesses declare that during their work is not used Delphi technique for promotion of group creativity, whereas $24 \%$ (911) of them declare that they use this technique. Results of this figure do not match with attitudes of managers and these results certify our twelfth hypothesis.

\section{Conclusions and Recommendations}

\subsection{Conclusions}

Majority of managers at Kosovo businesses declare that in their working environment, promote individual creativity to generate new ideas during the meeting with problems and process of decision making. They say that have created such a working environment where their employees freely can take and express initiatives and ideas that helps in process. Whereas they recognize and reward ideas of talented employees, because this encourages them to be more active and 
to give new useful ideas.

Majority of managers at Kosovo businesses declare that they promote group creativity by using technique of Brainstorming where they meet face to face with employees to generate ideas that help in making decisions. They also say that they use technique of nominal group where they describe problem and employees in independent way write the solutions than discuss and choose the best idea. Also Delphi technique that presents a written approach towards the creative solution of the problem, they say that they use to promote group creativity.

Majority of employees at Kosovo businesses declare that at the environment where they work is not promoted individual creativity to give new ideas that help in process of decision making they declare they cannot take free initiatives to give the ideas and does not happen to recognize and reward talented employees that give good ideas that help in process of decision making.

Majority of employees at Kosovo businesses declare that at their working environment is not promoted group creativity and does not happen to be used technique of "Brainstorming", where they meet face to face with managers to give ideas, or technique of nominal group where managers describe the problem, and they in independent way write the solutions than discuss and choose the best idea or even technique of Delphi that presents a written approach to the creative solution of the problem.

\subsection{Recommendations}

Majority of managers at Kosovo businesses are recommended to keep and develop these theoretical attitudes that stand for promotion of individual creativity because this is the best way to generate ideas and to make right decisions in time and in difficult situations during their work. And that their orientation has to be done in maximum practice implemented of this knowledge.

Majority of managers at Kosovo businesses are recommended to keep and develop these theoretical attitudes that stand for promotion of group creativity because this is the best way to generate ideas and to have in disposition more alternatives during their work that help to make right decisions in time and in difficult situations. And that implementation in practice of this knowledge it is more useful.

Majority of managers at Kosovo businesses are recommended to promote individual creativity because they will have in disposition more decision making alternatives and will be closer to right decisions, so their efforts should be orientated in that direction to create an environment where employees express freely their ideas and this make them to feel part of responsibility process. Also should recognize and reward talented employees because this motivates them and make them more active, so managers should apply their theoretical attitudes also in practice because they have no value if they are not implemented.

Majority of managers at Kosovo businesses are recommended to promote individual creativity because they will have in disposition more decision making alternatives and to do this by using possible techniques that are: Brainstorming, Nominal Group, and Delphi technique. Through these techniques will be find opportunities for employees to be more effective in providing ideas, by finding themselves in the best form that fits to them and alternatives of decision making definitely will be more creative.

\section{References}

Koleci, B., F. Reçica \& N. Turkeshi (2008):"Menaxhment", Prishtinë, AAB.

Konini, M., I. Peçi, (1997):"Fjalor Ekonomik", Tiranë, CIVET.

Kuka, I., Pula, J., Krasniqi, B. (2006):"Menaxhmenti dhe vendosja",Prishtinë, Universiteti i Prishtines.

Llaci,Sh.(2002):"Menaxhimi", Tiranë, ALB PAPER

Massic J. L. \& J. Douglas, (1973):"Managing: Acontemporary Introduction", Perntace Hall. Engewood Cliffs.

Ramosaj, B. (2007): "Bazat e Menaxhimit", Prishtinë, Universiteti i Prishtinës.

Ramosaj, B. (1991):" Ndërmarrja dhe menaxhmenti ndërmarrës", Prishtinë, Rilindja.

Robbins, S., D. DeCenzo, (2011):"Bazat e Menaxhimit", Tiranë, UET/Press.

Skenderi, N. (2010):"Fjalor Ekonomiko-Social", Prishtinë, AKB.

Weihrich, H. \& H. Koontz, (1993):"Management", New York, Copyright McGraw.

Zeqiri, I., (2006):"Menaxhmenti", Tetovë, Tringa Design. 